\title{
DETERMINANTS AND MARGINAL VALUE OF CORPORATE CASH HOLDINGS: FINANCIAL CONSTRAINTS VERSUS CORPORATE GOVERNANCE
}

\author{
Wenchien Liu, Chung Yuan Christian University
}

\begin{abstract}
Previous studies indicate that financial constraints and corporate governance are main factors affecting corporate cash holdings. This paper simultaneously examines the interactive influences of financial constraints and corporate governance on corporate cash holdings among publicly traded U.S. firms. We find that firms with good governance hold more cash than do firms with poor governance, regardless of financial constraints. Furthermore, the cash holdings of financially constrained firms with good corporate governance are the highest among all firm types in this study. The impact of corporate governance on firm value is statistically strong only among firms with financial constraints. Our results indicate that financial constraints are a more crucial determinant of corporate cash holdings than is corporate governance. These findings have implications that firms with financial constraints should pay more attention to keep optimal liquidity, especially avoiding the unnecessary waste due to agency problems.
\end{abstract}

JEL: G32, G34

KEYWORDS: Corporate Cash Holdings, Corporate Governance, Financial Constraints

\section{INTRODUCTION}

$\mathrm{T}$ The determinants of corporate cash holdings are critical to corporate finance theories. Managers often strive to maintain an optimal level of liquid assets to balance the various costs and benefits associated with varying degrees of liquidity. Kim, Mauer, and Sherman (1998) find that U.S. industrial firms often engage in trade-offs between low returns earned on liquid assets and the benefits of minimizing the need for costly external financing. Opler, Pinkowitz, Stulz, and Williamson (1999) report evidence that is consistent with static trade-off models of cash holdings. A series of subsequent studies further examine the various determinants of corporate cash holdings. The two principal factors in the literature are corporate governance (Dittmar and Mahrt-Smith, 2007; Harford, Mansi, and Maxwell, 2008; Yun, 2009; Gao, Harford, and Li, 2013) and financial constraints (Almeida, Campello and Weisbach, 2004; Faulkender and Wang, 2006; Denis and Sibilkov, 2009; Campello, Graham, and Harvey, 2010). However, these studies focus only on the individual effects of these two factors on corporate cash holdings and do not investigate their interactive effects. Hence, in the present study, we simultaneously examine and compare the interactive effects of corporate governance and financial constraints on corporate cash holdings. First, agency problems play an essential role in corporate cash holdings. Dittmar and Mahrt-Smith (2007) find that corporate governance strongly affects the value of cash holdings, and firms with poor corporate governance often hold fewer cash reserves in the U.S. market.

Harford, Mansi, and Maxwell (2008) also use U.S. firm data to examine the relationship between corporate governance and cash holdings. The researchers find that firms with excess cash holdings and poor corporate governance often rapidly spend cash on capital expenditures and acquisitions. Empirical evidence of the U.S. market indicates that firms with poor corporate governance often hold fewer cash reserves and the value of cash holdings is lower than firms with good corporate governance. Gao, Harford, and Li (2013) focus on private U.S. firms and find agency problems related to the determinants of corporate cash holdings. In addition, some researchers use international data to explore the determinants 
of corporate cash holdings. Dittmar, Mahrt-Smith, and Servaes (2003) show the importance of agency problems for determining corporate cash holdings. The researchers find that countries with poor shareholder protection rights often have higher cash holdings after controlling for capital market development. Using international data, Pinkowitz, Stulz, and Williamson (2006) and Kalcheva and Lins (2007) compare the value of cash holdings in countries with strict and lenient investor protection laws. The researchers find that the marginal contributions of corporate cash holdings to firm value are weaker in countries with low levels of investor protection. In summary, evidence from studies conducted in multiple countries shows that firms with poor corporate governance often hold more cash and the value of their cash holdings is lower, which contradicts the findings in the U.S. market. Hence, further analysis is required to understand why the empirical results vary widely.

Another branch of literature explores the link between financial constraints and corporate cash holdings. Keynes (1934) and Opler, Pinkowitz, Stulz, and Williamson (1999) illustrate the precautionary benefits of holding liquid assets and show that firms that are financially constrained tend to hold more cash. Almeida, Campello, and Weisbach (2004) show that firms with financial constraints save more cash from cash flow. Faulkender and Wang (2006) find that the marginal value of cash reserves declines with larger cash holdings, higher leverage, and more access to capital markets. Acharya, Almeida, and Campello (2007) demonstrate that cash does not constitute negative debt because firms are financially constrained. However, because firms with good corporate governance should not be financially constrained, these findings seem to contradict those of Dittmar and Mahrt-Smith (2007) and Harford, Mansi, and Maxwell (2008), who find that firms with good corporate governance often hold more cash and the value of cash holdings is higher for these firms. Hence, again, further integrative and comparative analyses are required to recognize the real impact of these two critical determinants.

In summary, previous empirical results show that the effects of corporate governance on firm cash holdings in the United States and in international markets are not accordant with each other. Previous studies also show that corporate governance and financial constraints are significant determinants of corporate cash holdings; however, the findings of related studies are mixed, possibly because these studies omit the interactive effects of crucial factors, especially corporate governance and financial constraints. Hence, the questions we ask in this paper are designed to gain an understanding of the interactive relationship between these two factors and which factor is more crucial for corporate cash holdings. To avoid overestimating the impact of corporate governance or financial constraints on corporate cash holdings, we consider both factors in examining the determinants of corporate cash holdings in our empirical settings.

Our research contributes to the literature in three manners. First, we simultaneously examine the effects of corporate governance and financial constraints on corporate cash holdings. Our results show that firms with good corporate governance that are financially constrained often hold more cash. Second, we find that corporate governance exerts less of an influence on cash holdings than do financial constraints. Third, we examine the marginal value of cash holdings. Our results show that when firms are financially constrained, the difference in marginal cash value between good and poor governance is high, whereas when firms are not financially constrained, the difference in marginal cash value between good and poor governance is low. The paper proceeds as follows. We first review the literature about the determinants of corporate cash holdings in next section. Then, we describe the data and methodology. We also describes the empirical strategy and discusses the main results. Finally, we conclude in the final section.

\section{LITERATURE REVIEW}

\section{Financial Constraints and Corporate Cash Holdings}

At first, regarding the effects of financial constraints on corporate cash holdings, it can be traced back to Keynes (1934), who propose that holding liquid assets has the benefits of precaution. Opler, Pinkowitz, Stulz, and Williamson (1999) expand to provide empirical evidence that financing constraint is an important factor to promote those constrained firms to hold more cash due to precautionary motivation. 
After that, there are two influential studies leading the following studies recently. The first one is that Almeida, Campello, and Weisbach (2004) who propose a theoretical model and provide empirical evidences, showing that constrained firms tend to save more cash from cash flow. Furthermore, not focusing on the level of corporate cash holding, Faulkender and Wang (2006) propose the framework of semi-quantitative predictions to find the marginal value of an extra dollar of cash holding. They also find that the marginal value of corporate cash holding is related to the level of cash holding, leverage, access to capital markets, and the method of cash distribution. Based on the important contributions of Almeida, Campello, and Weisbach (2004) and Faulkender and Wang (2006), there are a serious of studies to provide additional factors affecting the relation between financial constraint and corporate cash holding. For example, Denis and Sibilkov (2009) examine why cash holdings are more valuable for financially constrained firms than for unconstrained firms, they find that it is related to the levels of investment for constrained firms. Ramezani (2011) use the method of real options to measure financing constraints, and find that firms with valuable real options hold excess cash. Lee and Park (2016) find that board governance standards play the substitution role for financial constraints in the determinants of corporate cash holdings.

\section{Corporate Governance and Corporate Cash Holdings}

Secondly, corporate governance also play an important role for the determinant of corporate governance. However, the empirical results from U.S. market and non-U.S. markets are not coherent. For example, both of Dittmar and Mahrt-Smith (2007) and Harford, Mansi, and Maxwell (2008) find that U.S. firms with poor corporate governance often hold less cash holdings due to spending largely on capital expenditures, acquisitions, and so on. On the contrary, regarding the evidences from non-U.S. markets, Dittmar, Mahrt-Smith, and Servaes (2003) find that countries with poor shareholder protection rights often hold more cash. Pinkowitz, Stulz, and Williamson (2006) and Kalcheva and Lins (2007) find that the marginal value of corporate cash holding to firm value are weaker in countries with low levels of investor protection. Overall, despite the different findings in U.S. and non-U.S. markets, all of them point out that corporate governance play an important role for the determinants of corporate cash holdings.

\section{$\underline{\text { Other Determinants for Corporate Cash Holdings }}$}

Finally, in addition to the financial constraints and corporate governance, some studies also propose other determinants or provide various perspectives for corporate cash holdings as follows. At first, focusing the United States market, Myers and Rajan (1998) discuss the paradox of liquidity. Pinkowitz and Williamson (2007) investigate the marginal value of cash in various industries of the United States. Foley, Titman, and Twite (2007) examine the effect of tax regulation on corporate cash holdings among the United States multinational firms. Bates, Kahle, and Stulz (2009) investigate the causes of higher cash holdings among U.S. industrial firms and find the main cause to be precaution motives not agency problems. Acharya, Davydenko, and Strebulaev (2012) investigate the relationship between credit risk and cash holdings and find that firms facing higher credit risk prefer higher cash holdings because of precautionary savings. Acharya, Almeida, and Campello (2013) examine aggregate risk and the choice between cash and lines of credit, and find that firms with higher risk have more cash holdings than credit lines. In contrast to studies that use only data from public firms, Gao, Harford, and Li (2013) focus on private the United States firms and find that private firms hold fewer cash holdings than do public firms. Azar, Kagy, and Schmalz (2016) illustrate the cost-of-carry perspective to explain the dynamics of corporate cash holdings. Then, performing international comparison among countries, Pinkowitz and Williamson (2001) compare empirical evidence from the United States, Japan and Germany to examine the effects of bank power on corporate cash holdings. Ramirez and Tadesse (2007) examine the relationships among corporate cash holdings, national culture, and multinationality. Begenau and Palazzo (2017) and Hsu, Li, and Lin (2016) investigate the effects of research-and-development-intensive firms on corporate cash holdings, which the former focus on firms in the United States and the latter focus on 23 other countries. 


\section{DATA AND METHODOLOGY}

\section{Model Specification}

This study investigates the determinants and marginal value of corporate cash holdings from the perspectives of corporate governance and financial constraints. First, we separately calculate the mean and median values of the cash holdings ratio categorized based on corporate governance and financial constraints. We then explore the interaction effects of these two factors on corporate cash holdings. Four interaction effects are observed, namely firms with good corporate governance and financial constraints, firms with poor corporate governance and financial constraints, firms with good corporate governance and no financial constraints, and firms with poor corporate governance and no financial constraints. We calculate the mean and median values of the cash holdings ratios for these four criteria and discuss the effects of corporate governance and financial constraints on corporate cash holdings. Following Faulkender and Wang (2006) and Dittmar and Mahrt-Smith (2007), we measure the marginal value of corporate cash holdings by using equation (1) and use excess return to measure firm value. The difference between equations (1) and (2) lies in the measurement of corporate governance; in equation (1), we use the G-Index (Gompers, Ishii, and Metrick, 2003), whereas in equation (2), we use the E-Index (Bebchuk, Cohen, and Ferrell, 2008).

$$
\begin{aligned}
& r_{i, t}-R_{i, t}^{B}=\alpha_{0}+\beta_{1} \frac{\Delta C_{i, t}}{M_{i, t-1}}+\beta_{2} \text { GindxDM } \times \Delta C_{i, t}+\beta_{3} \text { GindxDM }+\beta_{4} \frac{\Delta E_{i, t}}{M_{i, t-1}}+\beta_{5} \frac{\Delta N A_{i, t}}{M_{i, t-1}}+\beta_{6} \frac{\Delta R D_{i, t}}{M_{i, t-1}}+ \\
& \beta_{7} \frac{\Delta I_{i, t}}{M_{i, t-1}}+\beta_{8} \frac{\Delta D_{i, t}}{M_{i, t-1}}+\beta_{9} \frac{C_{i, t-1}}{M_{i, t-1}}+\beta_{10} \frac{L_{i, t}}{M_{i, t-1}}+\beta_{11} \frac{N F_{i, t}}{M_{i, t-1}}+\beta_{12} \frac{C_{i, t-1}}{M_{i, t-1}} \frac{\Delta C_{i, t}}{M_{i, t-1}}+\beta_{13} L_{i, t} \frac{\Delta C_{i, t}}{M_{i, t-1}}+\varepsilon_{i, t} \\
& r_{i, t}-R_{i, t}^{B}=\alpha_{0}+\beta_{1} \frac{\Delta C_{i, t}}{M_{i, t-1}}+\beta_{2} \operatorname{Eind} d x M \times \Delta C_{i, t}+\beta_{3} \operatorname{Eind} x D M+\beta_{4} \frac{\Delta E_{i, t}}{M_{i, t-1}}+\beta_{5} \frac{\Delta N A_{i, t}}{M_{i, t-1}}+\beta_{6} \frac{\Delta R D_{i, t}}{M_{i, t-1}}+ \\
& \beta_{7} \frac{\Delta I_{i, t}}{M_{i, t-1}}+\beta_{8} \frac{\Delta D_{i, t}}{M_{i, t-1}}+\beta_{9} \frac{C_{i, t-1}}{M_{i, t-1}}+\beta_{10} \frac{L_{i, t}}{M_{i, t-1}}+\beta_{11} \frac{N F_{i, t}}{M_{i, t-1}}+\beta_{12} \frac{C_{i, t-1}}{M_{i, t-1}} \frac{\Delta C_{i, t}}{M_{i, t-1}}+\beta_{13} L_{i, t} \frac{\Delta C_{i, t}}{M_{i, t-1}}+\varepsilon_{i, t}
\end{aligned}
$$

The dependent variables are excess return, $r_{i, t}-R_{i, t}^{B}$, where $r_{i, t}$ is an individual firm's annual stock return and $R_{i, t}^{B}$ is the Fama and French (1993) 25-size and book-to-market matched portfolio return. The independent variable includes the change in cash holdings deflated by the lagged market value of equity $\left(\Delta C_{i, t} / M_{i, t-1}\right)$ and the interaction term between corporate governance dummy variables (G-Index in equation (1) and E-Index in equation (2)). We also include some control variables such as change in cash holdings (GindexDM* $\Delta C_{i, t}$ in equation (1] and EindexDM* $\Delta C_{i, t}$ in equation (2)), the corporate governance dummy variable, change in earnings before extraordinary items deflated by the lagged market value of equity $\left(\Delta E_{i, t} / M_{i, t-1}\right)$, change in net assets deflated by the lagged market value of equity $\left(\Delta N A_{i, t} /\right.$ $\left.M_{i, t-1}\right)$, change in research and development expenses deflated by the lagged market value of equity ( $\Delta$ $\left.R D_{i, t} / M_{i, t-1}\right)$, change in interest expenses deflated by the lagged market value of equity $\left(\Delta I_{i, t} / M_{i, t-1}\right)$, change in common dividends deflated by the lagged market value of equity $\left(\Delta D_{i, t} / M_{i, t-1}\right)$, lagged cash deflated by the lagged market value of equity $\left(C_{i, t-1} / M_{i, t-1}\right)$, leverage from the lagged market value of equity $\left(L_{i, t} / M_{i, t-1}\right)$, new finance deflated by the lagged market value of equity $\left(N F_{i, t} / M_{i, t-1}\right)$, the interaction term between lagged cash deflated by the lagged market value of equity $\left(C_{i, t-1} / M_{i, t-1}\right)$, change in cash deflated by the lagged market value of equity $\left(\Delta C_{i, t} / M_{i, t-1}\right)$, and the interaction term between leverage and change in cash deflated by the lagged market value of equity $\left(\Delta C_{i, t} / M_{i, t-1}\right)$. 
To compare the impact of financial constraints and corporate governance on corporate cash holdings, we divide our samples into two groups, namely financial constraint and no financial constraint. We also test the marginal value of cash holdings for the following four groups: firms with good corporate governance and financial constraints, firms with poor corporate governance and financial constraints, firms with good corporate governance and no financial constraints, and firms with poor corporate governance and no financial constraints.

\section{B. Data Description}

Our U.S. market data are retrieved from Compustat, CRSP, and the Investor Responsibility Research Center (IRRC). In addition, we use Fama and French (1993) 25-size and book-to-market matched portfolio returns to calculate excess returns. Detailed variable definitions are provided in Table 1. In order to more closely compare with the empirical findings of Faulkender and Wang (2006) and Dittmar and Mahrt-Smith (2007), our sample periods are also started from 1990 with the time length of seventeen years, which finally yields 9,696 firm-year observations. Excess return $\left(r_{i, t}-R_{i, t}^{B}\right)$ is calculated from $r_{i, t}$, which is an individual firm's stock return. $R_{i, t}^{B}$ is the benchmark portfolio return, which is the Fama and French (1993) 25-size and book-to-market matched portfolio return. Some variables and financial ratios are used in this study, including cash $\left(C_{i, t}\right)$, cash holdings ratios $\left(\mathrm{CH}_{i, t}\right)$, earnings before extraordinary items $\left(E_{i, t}\right)$, net assets $\left(N A_{i, t}\right)$, research and development $\left(R D_{i, t}\right)$, interest expenses $\left(I_{i, t}\right)$, common dividends $\left(D_{i, t}\right)$, leverage $\left(L_{i, t}\right)$, and new finance $\left(N F_{i, t}\right)$. These variables are collected from Compustat.

Following previous studies, we use two corporate governance indices in this study, namely the G-Index (Gompers, Ishii, and Metrick, 2003) and E-Index (Bebchuk, Cohen, and Ferrell, 2008). Both indices are constructed based on the IRRC surveys of investor rights and takeover protection. Because these IRRC surveys are not conducted every year, we follow the literature by assuming that the indices remain unchanged in the year following the most recent report. That is, for example, the G-Index or E-Index of 1995 is used for all time periods after the publication of the 1990 edition until the G-Index or E-Index of the 1998 edition are available. Gompers, Ishii, and Metrick (2003), Bebchuk, Cohen, and Ferrell (2008), Faulkender and Wang (2006), and Dittmar and Mahrt-Smith (2007) all adopt this setting. Then, in the G-Index of Gompers, Ishii, and Metrick (2003), one point is added for every provision that reduces shareholder rights (24 provisions in total), and thus firms in the higher deciles of the index are referred to as having weaker shareholder rights (poor corporate governance).

The difference between the G-Index and E-Index is that E-Index only choose six provisions have the greatest impact on firm value. We divide the sample into two groups based on the median values of the G-Index and E-Index and create binary dummy variables as proxies for corporate governance. We also follow Almeida, Campello, and Weisbach (2004) and Faulkender and Wang (2006) to measure corporate financial constraints based on four criteria: sales, size, bond ratings, and payout ratio. These variables are collected from the Compustat. In addition, based on these four criteria, we split the sample into two groups: firms that are and are not financially constrained. Table 2 reports the summary statistics for all variables used in this study. 


\section{Table 1: Variables Definition}

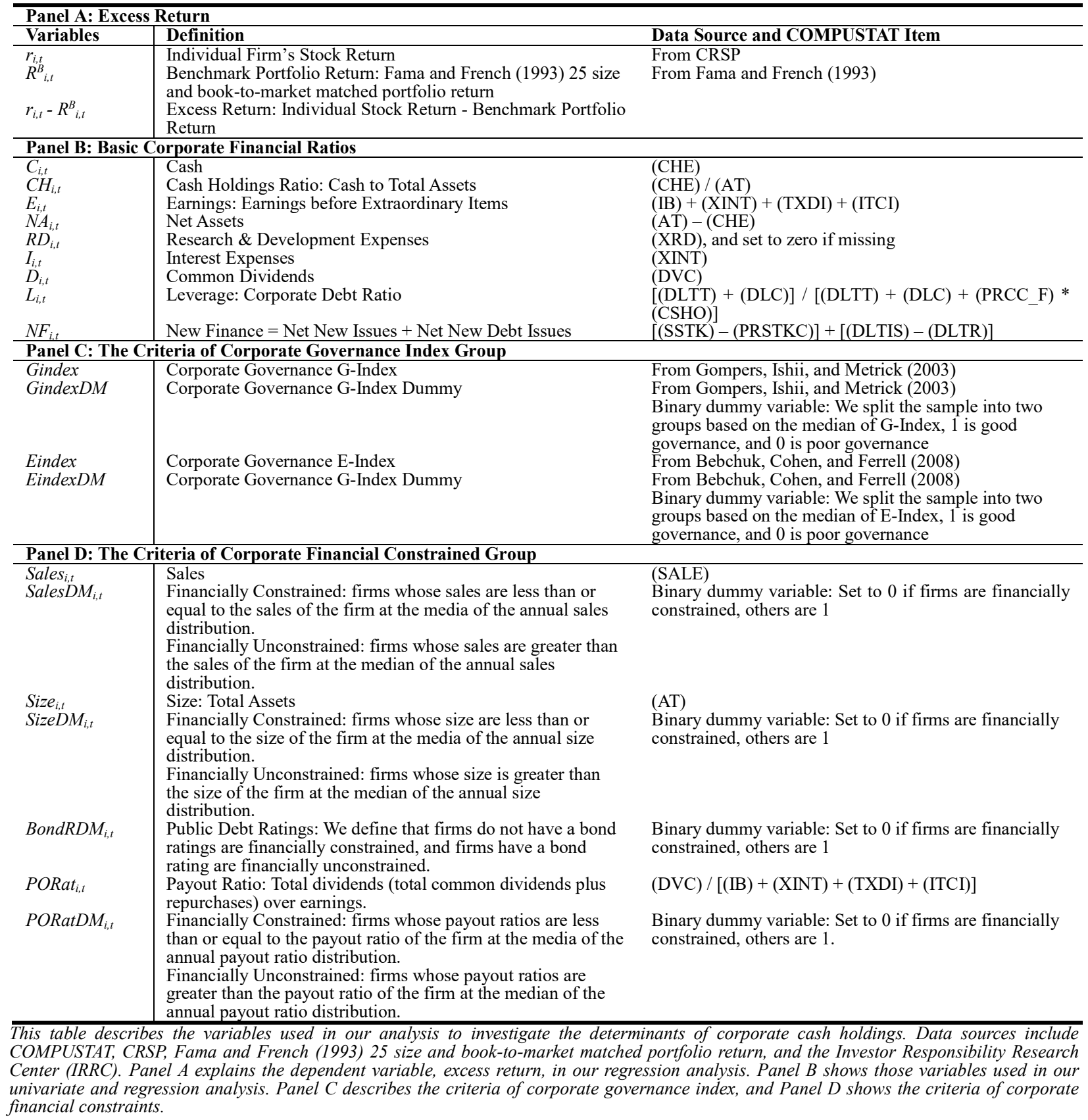


Table 2: Summary Statistics

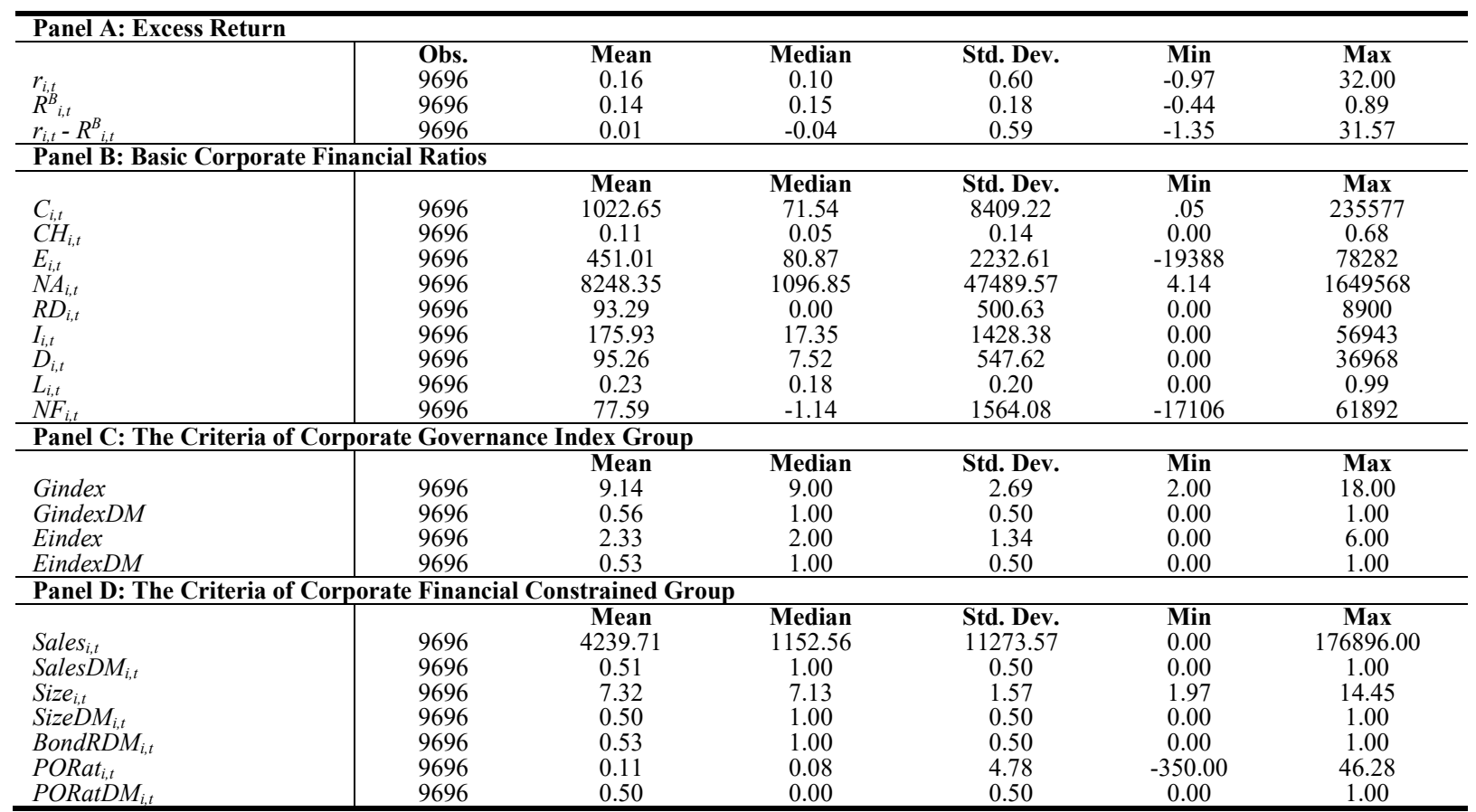

This table provides all descriptive statistic for our sample, which is selected from COMPUSTAT in a manner consistent with the combination of Faulkender and Wang (2006), and Dittmar and Mahrt-Smith (2007). The variables definition are identical in Table 1. Data are trimmed for the key variable, $\mathrm{CH}_{i, t}$, at the $1^{\text {st }}$ and $99^{\text {th }}$ percentiles to avoid the influence of extreme observations.

\section{EMPIRICAL RESULTS}

\section{Corporate Cash Holdings}

The determinants of corporate cash holdings are discussed in this section. First, we compare the individual impacts of corporate governance and financial constraints on corporate cash holdings. We subsequently discuss the interaction effects of these two variables. The empirical results are shown in Table 3. Panel A and Panel B of Table 3 shows the mean and median values of corporate cash holdings for whole sample and firms with good corporate governance and bad corporate governance, respectively. Using the G-Index and E-Index of the governance measurements, we find that firms with good governance hold more cash than firms with poor governance, which is consistent with the inferences of Harford, Mansi, and Maxwell (2008). Taking the measurement of the G-Index as an example, the mean (median) values of the corporate cash holdings ratio for firms with poor governance are $0.0926(0.0446)$, while those for firms with good governance are $0.1291(0.0675)$. The results obtained using the E-Index as a proxy for corporate governance are similar. Overall, we can find that corporate governance has a crucial effect on corporate cash holdings.

Panel $\mathrm{C}$ of Table 3 provides the mean and median values of corporate cash holdings for firms with and without financial constraints. Following Almeida, Campello, and Weisbach (2004) and Faulkender and Wang (2006), we adopt four criteria, namely sales, size, bond ratings, and payout ratio, to measure the extent of corporate financial constraints. Take the sales criterion for example, it shows that the mean (median) values of corporate cash ratios for firms with and without financial constraints are 0.1373 (0.0722) and 0.0893 (0.0449), respectively. The differences in corporate cash holdings between firms with and without financial constraints are statistically significant at the $1 \%$ level. The other three criteria also yield identical results, indicating that financial constraints can affect corporate cash holdings. This finding is consistent with those of Almeida, Campello, and Weisbach (2004). 
Table 3: Corporate Cash Holdings, Corporate Governance and Financial Constraints

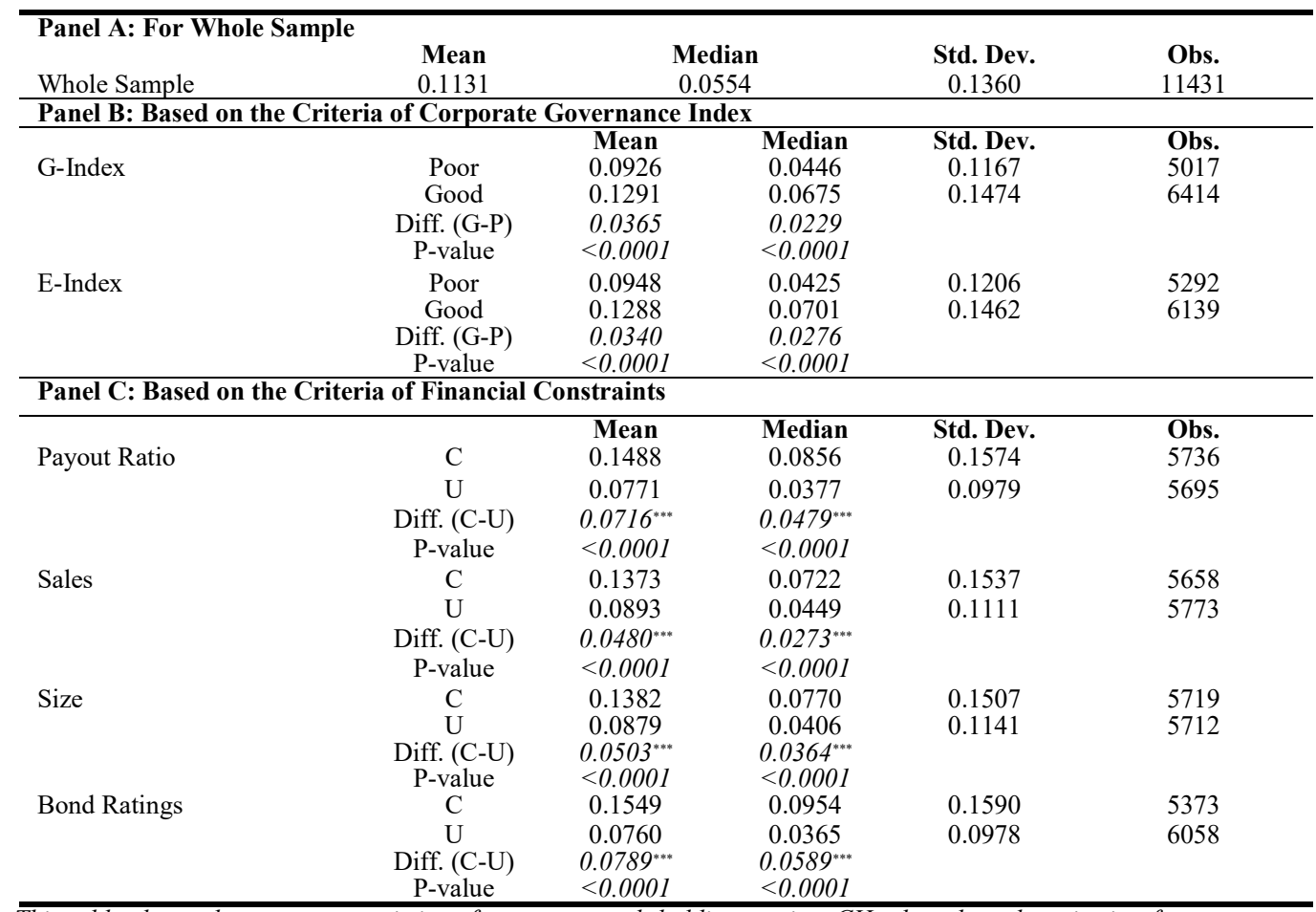

This table shows the summary statistics of corporate cash holdings ratios, $\mathrm{CH}_{i, t}$, based on the criteria of corporate governance and corporate financial constraints. Panel A reports the result for the full sample. Panel B, shows the mean and median values of corporate cash holdings for firms with good corporate governance and poor corporate governance. We use two criteria to measure corporate governance. One is the G-Index of Gompers, Ishii, and Metrick (2003), and the other one is the E-Index of Bebchuk, Cohen, and Ferrell (2008). The symbols "Poor", "Good", "Diff. $(G-P)$ ", and "P-value" below "Diff. (G-P)" represent firms with poor governance, good governance, the mean or median value of cash holdings for those firms are with poor governance minus for those firms are with good governance, and the p-value for the null hypothesis of "Diff. (G-P) is zero", respectively. Panel $C$, shows the mean and median values of corporate cash holdings for firms that are financially constrained and unconstrained. For robustness checks, we adopt four criteria to measure whether firms are financial constrained. They include sales, firm size, bond ratings, and payout ratio. The symbols " $C$ ", " $U$ ", "Diff. $(C-U)$ ", and "P-value" next to "Diff. (C-U)" represent firms that are financially constrained, firms are financially unconstrained, the mean or median value of cash holdings for those firms are financial constrained minus for those firms are financial unconstrained, and the p-value for the null hypothesis of "Diff. (C-U) is zero", respectively. The corporate cash holdings ratios variable, $\mathrm{CH}_{i, t}$ is trimmed at the $1^{\text {st }}$ and $99^{\text {th }}$ percentiles to avoid the influence of extreme observations. $* * *, * * *$ indicate significance at $10 \%, 5 \%$, and $1 \%$ level, respectively.

\section{Interaction Effects of Corporate Governance and Financial Constraints on Corporate Cash Holdings}

To examine the interaction effects of corporate governance and financial constraints on corporate cash holdings, we divide the full sample into four groups as follows. They are firms with good corporate governance and are financial constraints, firms with poor corporate governance and financial constraints, firms with good corporate governance and no financial constraints, and firms with poor corporate governance and no financial constraints. Then, we compare the mean and median values of the cash holdings ratios for these groups. The results are described in Table 4. Panel A of Table 4 shows that firms with financial constraints and good corporate governance have higher cash holding ratio. Take the interaction using the criterion of Sales and G-Index for example (in left-up panel), we can find that firms with financial constraints and good corporate governance have higher cash holding ratio (i.e., the mean value is 0.1504 ) than the remaining three combinations, including those firms with financial constraints and poor corporate governance $(0.1137)$, firms with good corporate governance and no financial constraints (0.1011), and firms with poor corporate governance and no financial constraints (0.0785). Furthermore, focusing on comparing the two groups for those firms with and without financial constraints, we can find that the difference between firms with good and poor governance for the group without financial constraints is smaller (0.0226) than the group with financial constraints $(0.0367)$. In addition to the combination using the criterion of Sales and G-Index, we also find that the combinations using other criterions also present identical results. 
Table 4: Corporate Cash Holdings and the Interaction of Corporate Governance and Financial Constraints

\begin{tabular}{|c|c|c|c|c|c|c|c|c|c|}
\hline & \multicolumn{5}{|c|}{ anel A: The Mean Value of Corporate Cash Holdings Ratio } & E-Index & & & \\
\hline & & Poor & Good & $\begin{array}{c}\text { Diff. } \\
\text { (G-P) }\end{array}$ & P-value & Poor & Good & $\begin{array}{c}\text { Diff. } \\
\text { (G-P) }\end{array}$ & P-value \\
\hline \multirow[t]{4}{*}{ Sales } & $\mathrm{C}$ & 0.1137 & 0.1504 & $0.0367^{* * *}$ & $<0.0001$ & 0.1168 & 0.1527 & $0.0360^{* * *}$ & $<0.0001$ \\
\hline & $\mathrm{U}$ & 0.0785 & 0.1011 & $0.0226^{* * *}$ & $<0.0001$ & 0.0762 & 0.1022 & $0.0259^{* * *}$ & $<0.0001$ \\
\hline & Diff. (C-U) & $0.0352^{* * *}$ & $0.0493^{* * *}$ & & & $0.0405^{* * *}$ & $0.0505^{* * *}$ & & \\
\hline & P-value & $<0.0001$ & $<0.0001$ & & & $<0.0001$ & $<0.0001$ & & \\
\hline \multirow[t]{4}{*}{ Size } & C & 0.1129 & 0.1535 & $0.0406^{* * *}$ & $<0.0001$ & 0.1199 & 0.1527 & $0.0328^{* * *}$ & $<0.0001$ \\
\hline & $\mathrm{U}$ & 0.0773 & 0.0986 & $0.0213^{* * *}$ & $<0.0001$ & 0.0719 & 0.1029 & $0.0310^{* * *}$ & $<0.0001$ \\
\hline & Diff. (C-U) & $0.0356^{* * *}$ & $0.0549^{* * *}$ & & & $0.0481^{* * *}$ & $0.0498^{* * *}$ & & \\
\hline & P-value & $<0.0001$ & $<0.0001$ & & & $<0.0001$ & $<0.0001$ & & \\
\hline Bond & C & 0.1284 & 0.1692 & $0.0408^{* * *}$ & $<0.0001$ & 0.1334 & 0.1701 & $0.0367^{* * *}$ & $<0.0001$ \\
\hline \multirow[t]{3}{*}{ Ratings } & $\mathrm{U}$ & 0.0710 & 0.0813 & $0.0104^{* * *}$ & $<0.0001$ & 0.0669 & 0.0853 & $0.0185^{* * *}$ & $<0.0001$ \\
\hline & Diff. $(C-U)$ & $0.0575^{* * *}$ & $0.0879^{* * *}$ & & & $0.0666^{* * * *}$ & $0.0847^{* * *}$ & & \\
\hline & P-value & $<0.0001$ & $<0.0001$ & & & $<0.0001$ & $<0.0001$ & & \\
\hline Payout & $\mathrm{C}$ & 0.1277 & 0.1603 & $0.0327^{* * *}$ & $<0.0001$ & 0.1328 & 0.1599 & $0.0271^{* * *}$ & $<0.0001$ \\
\hline \multirow[t]{3}{*}{ Ratio } & $\mathrm{U}$ & 0.0687 & 0.0865 & $0.0178^{* * *}$ & $<0.0001$ & 0.0644 & 0.0907 & $0.0264^{* * *}$ & $<0.0001$ \\
\hline & Diff. (C-U) & $0.059^{m * *}$ & $0.0739^{* * *}$ & & & $0.0684^{* * *}$ & $0.0691^{* * *}$ & & \\
\hline & P-value & $<0.0001$ & $<0.0001$ & & & $<0.0001$ & $<0.0001$ & & \\
\hline \multicolumn{10}{|c|}{ Panel B: The Median Value of Corporate Cash Holdings Ratio } \\
\hline & & \multicolumn{4}{|c|}{ G-Index } & \multicolumn{4}{|c|}{ E-Index } \\
\hline & & Poor & Good & $\begin{array}{l}\text { Diff. } \\
\text { (G-P) }\end{array}$ & P-value & Poor & Good & $\begin{array}{c}\text { Diff. } \\
\text { (G-P) }\end{array}$ & P-value \\
\hline \multirow[t]{4}{*}{ Sales } & $\mathrm{C}$ & 0.0584 & 0.0845 & $0.0261^{* \text { *** }}$ & $<0.0001$ & 0.0553 & 0.0886 & $0.0332^{* * * *}$ & $<0.0001$ \\
\hline & U & 0.0373 & 0.0540 & $0.0167^{* * *}$ & $<0.0001$ & 0.0353 & 0.0556 & $0.0204^{* * *}$ & $<0.0001$ \\
\hline & Diff. (C-U) & $0.0211^{* * *}$ & $0.0305^{* * *}$ & & & $0.0201^{* * *}$ & $0.0329^{* * *}$ & & \\
\hline & P-value & $<0.0001$ & $<0.0001$ & & & $<0.0001$ & $<0.0001$ & & \\
\hline \multirow[t]{4}{*}{ Size } & $\mathrm{C}$ & 0.0620 & 0.0920 & $0.0300^{* * *}$ & $<0.0001$ & 0.0628 & 0.0920 & $0.0292^{* * *}$ & $<0.0001$ \\
\hline & $\mathrm{U}$ & 0.0347 & 0.0495 & $0.0149^{* * *}$ & $<0.0001$ & 0.0316 & 0.0533 & $0.0217^{* * *}$ & $<0.0001$ \\
\hline & Diff. (C-U) & $0.0273^{* * *}$ & $0.0425^{* * *}$ & & & $0.0312^{* * * *}$ & $0.0387^{* * *}$ & & \\
\hline & P-value & $<0.0001$ & $<0.0001$ & & & $<0.0001$ & $<0.0001$ & & \\
\hline Bond & $\mathrm{C}$ & 0.0748 & 0.1136 & $0.0388^{* * * *}$ & $<0.0001$ & 0.0753 & 0.1135 & $0.0382^{* * * *}$ & $<0.0001$ \\
\hline \multirow[t]{3}{*}{ Ratings } & U & 0.0333 & 0.0412 & $0.0080^{* * *}$ & $<0.0001$ & 0.0310 & 0.0451 & $0.0142^{* * *}$ & $<0.0001$ \\
\hline & Diff. (C-U) & $0.0415^{* * *}$ & $0.0723^{* * *}$ & & & $0.0444^{* * * *}$ & $0.0684^{* * *}$ & & \\
\hline & P-value & $<0.0001$ & $<0.0001$ & & & $<0.0001$ & $<0.0001$ & & \\
\hline Payout & $\mathrm{C}$ & 0.0671 & 0.0979 & $0.0308^{* * *}$ & $<0.0001$ & 0.0683 & 0.0982 & $0.0299^{* * *}$ & $<0.0001$ \\
\hline \multirow[t]{3}{*}{ Ratio } & U & 0.0345 & 0.0440 & $0.0095^{* * *}$ & $<0.0001$ & 0.0309 & 0.0494 & $0.0185^{* * *}$ & $<0.0001$ \\
\hline & Diff. (C-U) & $0.0326^{* * *}$ & $0.0539^{* * *}$ & & & $0.0374^{* * *}$ & $0.0488^{* * *}$ & & \\
\hline & P-value & $<0.0001$ & $<0.0001$ & & & $<0.0001$ & $<0.0001$ & & \\
\hline
\end{tabular}

This table reports results based on the interaction of corporate governance and financial constraints. Panel A shows the mean value of corporate cash holdings based on the interaction of these two factors, and Panel B shows the median value of corporate cash holdings. All the symbols used in this Table can be referred to those used in Table 3. The symbols "C", "U", "Diff. (C-U)", and "P-value" below "Diff. (C-U)" represent firms that are financially constrained, firms that are financially unconstrained, the mean or median value of cash holdings for those firms are financially constrained minus firms that are financially unconstrained, and the p-value for the null hypothesis of "Diff. (C-U) is zero". The symbols "Poor", "Good", "Diff. (G-P)", and "P-value" next to "Diff. (G-P)" represent firms with poor governance, good governance, the mean or median value of cash holdings for those firms with poor governance minus for firms with good governance, and the p-value for the null hypothesis of "Diff. $(G-P)$ is zero". The corporate cash holdings ratios variable, $\mathrm{CH}_{i, \mathrm{t}}$, is also trimmed at the $1^{\text {st }}$ and $99^{\text {th }}$ percentiles to avoid the influence of extreme observations. ***, *** indicate significance at $10 \%, 5 \%$, and $1 \%$ level, respectively.

Overall, these results illustrate that the impact of corporate governance on corporate cash holdings is greater among firms with financial constraints, implying the more crucial role of financial constraints. Finally, in order to avoid the potential bias from extreme value using mean value, we also provide the results for the median value of cash holding ratios on Panel B of Table 4 . The results are identical to those in Panel A, which shows the robustness for our results.

We go further to discuss the impact of corporate governance on corporate cash holdings is high only among firms with financial constraints here. It is possible that if shareholders rights are not strictly upheld, managers may spend corporate cash on unnecessary acquisitions and capital expenditure. Harford, Mansi, and Maxwell (2008) find evidence consistent with the spending hypothesis, implying that firms with poor governance often spend cash more quickly than do firms with good governance. If firms are financially unconstrained, they still can easily raise the funds necessary for regular investments and operations, and thus the quality of corporate governance may be less critical for corporate cash holdings. However, firms 
that are financially constrained and have poor shareholder rights may find it difficult to raise such funds. Hence, we find that among firms with financial constraints, the difference in corporate cash holdings between firms with good and poor governance is significant. Our results also have the implications that the impact of corporate governance on corporate cash holdings depends on whether a firm is financially constrained.

\section{Marginal Value of Corporate Cash Holdings}

In addition to the discussion about the interaction of financial constraints and corporate governance in last section, we go further to investigate the marginal value of corporate cash holdings. Following Faulkender and Wang (2006) and Dittmar and Mahrt-Smith (2007), we estimate the marginal value of corporate cash holdings by measuring the effects of change in cash holdings on change in firm value. Table 5 reports the regression results of equations (1) and (2) for the impact of corporate governance on the value of cash holdings for financial constrained and unconstrained firms. The results provided in Table 5 use the G-Index as the governance index. Take the first financial constraint measure of Sales for example, columns (1) and (2) show that changes in cash holdings $\left(\triangle C_{i, t} / M_{i, t-l}\right)$ have a significant and positive effect on firm value. Especially, the coefficient of changes in cash holdings for firms with financial constraints (1.7834) is larger than the firms without financial constraints $(0.6616)$, which imply financial constraints indeed play a more important role. The results obtained using different financial constraint measures are presented in columns (3)-(8), which are also quite similar. In addition, we also use the E-Index as another proxy for the governance index and yield identical results. We do not report this result of robustness checks here to save space, which will be provided upon request. Overall, the results show that changes in cash holdings have a significant and positive effect on firm value, especially for firms with financial constraints.

We calculate the marginal value of one dollar of cash to further determine the interaction effects of corporate governance and financial constraints in Table 6 . We first provide the mean value of each variable in Panel A of Table 6, which is one of the important elements for calculating the marginal value of cash. Then, we group our data into two levels of financial constraints (financially constrained and financially unconstrained) and three levels of corporate governance (poor governance, good governance, and average governance). Therefore, we have six combinations of financial constraints and corporate governance: (i) firms with financial constraints and good governance; (ii) firms with financial constraints and poor governance; (iii) firms with financial constraints and average governance; (iv) firms without financial constraints and with good governance; (v) firms without financial constraints and with poor governance; (vi) firms without financial constraints and with average governance.

We present the main results in Panel B of Table 6, which shows the marginal value of cash holding based on the interaction of corporate governance and financial constraints. Take the interaction between payout ratio and GindexDM for example, when firms are financially constrained (denoted $C$ ) and have good corporate governance (denoted Good), we determine the marginal value of cash to be $1.6541(=1.7834 *$ $1+0.5356 * 1 * 1+(-0.0106) * 0.1550 * 1+(-3.1517) * 0.2104 * 1)$. We also take the other two ones for examples by using poor corporate governance (denoted Poor) and average corporate governance (denoted Average). For the value of 1.1185 , the calculation is $=1.7834 * 1+0.5356 * 0 * 1+(-0.0106) * 0.1550 *$ $1+(-3.1517) * 0.2104 * 1$. For the value of 1.4639, the calculation is $=1.7834 * 1+0.5356 * 0.6448 * 1$ $+(-0.0106) * 0.1551 * 1+(-3.1517) * 0.2104 * 1$.

Overall, among firms with financial constraints, those with good governance have the highest marginal value of cash holdings (1.6541), followed by those with average governance (1.4639) and poor governance (1.1185). By contrast, the values of cash holdings for firms without financial constraints have insignificant differences across the three corporate governance levels. The results based on various financial constraint measurements (size, bond ratings, and payout ratio) and the alternative corporate governance index (E-Index) are similar. We conclude that corporate governance is positively related to firm value and this effect is more significant for firms that are financially constrained. 
Table 5: Regression Results for the Impact of Corporate Governance on the Value of Cash Holdings for Financial Constrained and Unconstrained Firms

\begin{tabular}{|c|c|c|c|c|c|c|c|c|}
\hline & \multicolumn{2}{|c|}{ Sales } & \multicolumn{2}{|c|}{ Size } & \multicolumn{2}{|c|}{ Bond Ratings } & \multicolumn{2}{|c|}{ Payout Ratio } \\
\hline & $C$ & $\bar{U}$ & $C$ & $\bar{U}$ & $C$ & $\bar{U}$ & $\bar{C}$ & $\bar{U}$ \\
\hline & (1) & (2) & (3) & (4) & (5) & (6) & (7) & (8) \\
\hline \multirow[t]{2}{*}{$\triangle C_{i, t} / M_{i, t-1}$} & $1.7834^{* * * *}$ & $0.6616^{* * *}$ & $1.4439^{* * *}$ & 0.7387 & $1.1186^{* * * *}$ & $1.0650^{* *}$ & $1.3461^{* * *}$ & $0.6095^{* * *}$ \\
\hline & $(0.5703)$ & $(0.2056)$ & $(0.3173)$ & $(0.4551)$ & $(0.2756)$ & $(0.4558)$ & $(0.4353)$ & $(0.1525)$ \\
\hline \multirow[t]{2}{*}{ Gindex $D M^{*} \triangle C_{i, t}$} & 0.5356 & -0.0185 & $0.8140^{*}$ & -0.1258 & $0.7159^{*}$ & -0.1267 & 0.2104 & 0.1124 \\
\hline & $(0.4788)$ & $(0.1001)$ & $(0.4659)$ & $(0.1999)$ & $(0.3925)$ & $(0.2075)$ & $(0.2641)$ & $(0.1819)$ \\
\hline \multirow[t]{2}{*}{ GindexDM } & 0.0200 & -0.0022 & 0.0218 & -0.0061 & $0.0366^{* *}$ & -0.0034 & -0.0004 & 0.0044 \\
\hline & $(0.0178)$ & $(0.0116)$ & $(0.0172)$ & $(0.0119)$ & $(0.0177)$ & $(0.0123)$ & $(0.0195)$ & $(0.0098)$ \\
\hline \multirow[t]{2}{*}{$\triangle E_{i, t} / M_{i, t-1}$} & $0.4343^{* * *}$ & $0.4359^{* * *}$ & $0.4709^{* * *}$ & $0.3104^{* * *}$ & $0.4842^{* *}$ & $0.4004^{* * *}$ & $0.4257^{* * *}$ & $0.7392^{* * *}$ \\
\hline & $(0.1495)$ & $(0.0726)$ & $(0.1490)$ & $(0.0940)$ & $(0.1894)$ & $(0.0810)$ & $(0.1203)$ & $(0.1178)$ \\
\hline \multirow{2}{*}{$\triangle N A_{i, t} / M_{i, t-1}$} & $0.1749^{* *}$ & 0.0467 & 0.2134 & 0.0489 & 0.1956 & 0.0544 & $0.1146^{* *}$ & $0.0597^{* *}$ \\
\hline & $(0.0873)$ & $(0.0243)$ & $(0.1167)$ & $(0.0355)$ & $(0.1213)$ & $(0.0371)$ & $(0.0483)$ & $(0.0285)$ \\
\hline \multirow[t]{2}{*}{$\triangle R D_{i, t} / M_{i, t-1}$} & $-10.1475^{* *}$ & -1.2354 & $-10.3248^{* *}$ & $-1.2837^{*}$ & $-10.5713^{* *}$ & $-1.5996^{* *}$ & $-9.4804^{* *}$ & -0.1372 \\
\hline & $(4.4146)$ & $(0.7933)$ & $(4.4180)$ & $(0.6765)$ & $(4.5700)$ & $(0.8046)$ & $(4.6105)$ & $(0.8955)$ \\
\hline \multirow[t]{2}{*}{$\triangle I_{i, t} / M_{i, t-1}$} & -0.4306 & $-1.2706^{* *}$ & $-2.2657^{* *}$ & -0.5027 & -1.9497 & -0.9853 & -0.9733 & $-3.0617^{* *}$ \\
\hline & (1.0947) & $(0.5208)$ & $(1.1382)$ & $(0.7202)$ & $(1.4234)$ & $(0.6558)$ & $(0.6143)$ & $(1.2981)$ \\
\hline \multirow[t]{2}{*}{$\triangle D_{i, t} / M_{i, t-1}$} & 0.3925 & -0.0416 & $0.7810^{* * *}$ & -0.1188 & $0.5828^{* * * *}$ & -0.1265 & 0.2246 & $0.3387^{*}$ \\
\hline & $(0.2804)$ & $(0.3190)$ & $(0.2282)$ & $(0.1005)$ & $(0.1782)$ & $(0.1006)$ & $(0.2329)$ & $(0.1917)$ \\
\hline \multirow[t]{2}{*}{$C_{i, t-1} / M_{i, t-1}$} & -0.0689 & -0.0052 & -0.0259 & $<0.0001$ & $-0.1450^{* * *}$ & -0.0012 & -0.0406 & $-0.0653^{*}$ \\
\hline & $(0.0724)$ & $(0.0176)$ & $(0.0698)$ & $(0.0221)$ & $(0.0522)$ & $(0.0265)$ & $(0.0285)$ & $(0.0366)$ \\
\hline \multirow[t]{2}{*}{$L_{i, t} / M_{i, t-1}$} & $-0.2351^{* * *}$ & $-0.1900^{* * *}$ & $-0.2525^{* * *}$ & $-0.1719^{* * *}$ & $-0.2842^{* * *}$ & $-0.1904^{* * *}$ & $-0.2539^{* * *}$ & $-0.1445^{* * *}$ \\
\hline & $(0.0520)$ & $(0.0425)$ & $(0.0563)$ & $(0.0432)$ & $(0.0629)$ & $(0.0447)$ & $(0.0527)$ & $(0.0352)$ \\
\hline \multirow[t]{2}{*}{$N F_{i, t} / M_{i, t-1}$} & -0.2306 & $-0.1134^{* *}$ & -0.2279 & -0.1115 & $-0.3201^{*}$ & -0.1113 & $-0.2336^{* *}$ & -0.1235 \\
\hline & $(0.1464)$ & $(0.0566)$ & $(0.1484)$ & $(0.0742)$ & $(0.1687)$ & $(0.0886)$ & $(0.1008)$ & $(0.0770)$ \\
\hline \multirow[t]{2}{*}{$\left(C_{i, t-1} / M_{i, t-1}\right) *\left(\triangle C_{i, t} / M_{i, t-1}\right)$} & -0.0106 & -0.0189 & 0.0341 & -0.0069 & $-0.1859^{* *}$ & 0.0325 & 0.0289 & $-0.3151^{* * *}$ \\
\hline & $(0.0739)$ & $(0.0316)$ & $(0.0549)$ & $(0.0346)$ & $(0.0936)$ & $(0.0290)$ & $(0.0289)$ & $(0.1085)$ \\
\hline \multirow[t]{2}{*}{$L_{i, t} *\left(\triangle C_{i, t} / M_{i, t-1}\right)$} & $-3.1517^{* * *}$ & -0.4611 & $-2.1524^{* * *}$ & -0.5930 & $-1.4656^{*}$ & -1.1497 & $-1.6289^{* * *}$ & -0.2964 \\
\hline & $(1.0475)$ & $(0.3465)$ & $(0.8289)$ & $(0.5762)$ & $(0.7869)$ & $(0.5571)$ & $(0.5944)$ & $(0.3985)$ \\
\hline \multirow[t]{2}{*}{ Constant } & 0.0457 & $0.0479^{* * *}$ & 0.0375 & $0.0488^{* * *}$ & 0.0397 & $0.0551^{* * *}$ & $0.0901^{* * *}$ & 0.0098 \\
\hline & $(0.0201)$ & $(0.0117)$ & $(0.0205)$ & $(0.0123)$ & $(0.0199)$ & $(0.0139)$ & $(0.0196)$ & $(0.0102)$ \\
\hline$R$-squared & 0.3208 & 0.0668 & 0.3346 & 0.0524 & 0.3361 & 0.4339 & 0.2746 & 0.0607 \\
\hline Observations & 4265 & 4894 & 4374 & 4785 & 4144 & 5015 & 4449 & 4710 \\
\hline
\end{tabular}

This table shows OLS regression results for the impact of corporate governance on the value of cash holdings for constrained and unconstrained groups following Faulkender and Wang (2006), and Dittmar and Mahrt-Smith (2007). We report the impact of corporate governance on the value of cash holdings using the G-Index for financially constrained and unconstrained groups. The symbols " $C$ " and " $U$ " represent firms that are financially constrained, and firms that are financially unconstrained, respectively. For robustness checks, we use four measures to proxy for financial constraints, which include payout ratio, sales, firm size, and bond ratings. The dependent variable in all the regressions is excess return, $r_{i, t}-R_{i, t}^{B}$, where $r_{i, t}$ is the individual firm's annual stock return, and $R_{i, t}^{B}$ is the Fama and French (1993) 25 size and book-to-market matched portfolio return. The independent variable includes change in cash deflated by the lagged market value of equity $\left(\Delta C_{i, t} / M_{i, t-1}\right)$, the interaction term between corporate governance dummy (G-Index dummy) and change in cash (GindexDM* $\Delta C_{i t}$ ) corporate governance dummy (GindexDM), change in earnings before extraordinary items deflated by the lagged market value of equity $\left(\Delta E_{i, t} / M_{i, t-1}\right)$, change in net assets deflated by the lagged market value of equity $\left(\Delta N A_{i, t} / M_{i, t-1}\right)$, change in research \& development expenses deflated by the lagged market value of equity $\left(\Delta R D_{i t} / M_{i t-1}\right)$, change in interest expenses deflated by the lagged market value of equity $\left(\Delta_{i, t} / M_{i t-1}\right)$, change in common dividends deflated by the lagged market value of equity $\left(\Delta D_{i t} / M_{i t-1}\right)$, lagged cash deflated by the lagged market value of equity $\left(C_{i t-1} / M_{i t-1}\right)$, leverage by the lagged market value of equity $\left(L_{i, t} / M_{i, t-1}\right)$, new finance deflated by the lagged market value of equity $\left(N F_{i, t} / M_{i, t-1}\right)$, the interaction term between lagged cash deflated by the lagged market value of equity $\left(C_{i, t-1} / M_{i, t-1}\right)$ and change in cash deflated by the lagged market value of equity $\left(\Delta C_{i, t} / M_{i,-1}\right)$, and the interaction term between leverage and change in cash deflated by the lagged market value of equity $\left(L_{i, t} *\left(\Delta C_{i, t} / M_{i, t-1}\right)\right)$. White heteroscedastic consistent standard errors are given in parentheses. $* * *, * * *$ indicate significance at $10 \%, 5 \%$, and $1 \%$ level, respectively. 
Table 6: The Marginal Value of Corporate Cash Holdings

\begin{tabular}{|c|c|c|c|c|c|c|c|c|c|}
\hline & & \multicolumn{2}{|c|}{ Payout Ratio } & \multicolumn{2}{|c|}{ Sales } & \multicolumn{2}{|c|}{ Size } & \multicolumn{2}{|c|}{ Bond Ratings } \\
\hline & & $C$ & $U$ & $C$ & $U$ & 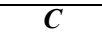 & $\bar{U}$ & $C$ & $U$ \\
\hline$C_{i, t-1}$ & & 0.1550 & 0.1344 & 0.1460 & 0.1422 & 0.1480 & 0.1408 & 0.2080 & 0.0836 \\
\hline$L_{i, t}$ & & 0.2104 & 0.2394 & 0.1907 & 0.2595 & 0.1487 & 0.2929 & 0.2296 & 0.2205 \\
\hline GindexDM & & 0.6448 & 0.4791 & 0.6235 & 0.4986 & 0.6490 & 0.4832 & 0.6456 & 0.4760 \\
\hline EindexDM & & 0.5712 & 0.5036 & 0.5581 & 0.5159 & 0.5861 & 0.4936 & 0.5894 & 0.4843 \\
\hline \multicolumn{10}{|c|}{ Panel B: Marginal Value of Cash Holdings Based on the Interaction of Corporate Governance and Financial Constraints } \\
\hline & & \multicolumn{2}{|c|}{ Payout Ratio } & \multicolumn{2}{|c|}{ Sales } & \multicolumn{2}{|c|}{ Size } & \multicolumn{2}{|c|}{ Bond Ratings } \\
\hline & & C & $U$ & $C$ & $\boldsymbol{U}$ & $C$ & $\boldsymbol{U}$ & C & $U$ \\
\hline \multirow[t]{3}{*}{ GindexDM } & Good & 1.6541 & 0.5301 & 1.8523 & 0.4581 & 1.5890 & 0.6062 & 1.1883 & 0.6302 \\
\hline & Poor & 1.1185 & 0.5486 & 1.0384 & 0.5838 & 0.8732 & 0.7329 & 0.9780 & 0.5178 \\
\hline & Average & 1.4639 & 0.5398 & 1.5459 & 0.5211 & 1.3378 & 0.6717 & 1.1138 & 0.5713 \\
\hline \multirow[t]{3}{*}{ EindexDM } & Good & 1.6961 & 0.5213 & 2.0690 & 0.5921 & 1.7246 & 0.7127 & 1.2362 & 0.5726 \\
\hline & Poor & 0.8745 & 0.5578 & 1.0653 & 0.3957 & 0.9280 & 0.6040 & 0.8694 & 0.5679 \\
\hline & Average & 1.4042 & 0.5403 & 1.6911 & 0.4937 & 1.4450 & 0.6565 & 1.1062 & 0.5701 \\
\hline
\end{tabular}

\section{CONCLUDING COMMENTS}

Previous studies show that both corporate governance and financial constraints have significant impacts on the levels of corporate cash holdings. This study examines the interaction effects of corporate governance and financial constraints on the holding and the marginal value of corporate cash holdings. Especially, we examine these two factors simultaneously to determine which factor is more important. Hence, we follow Almeida, Campello, and Weisbach (2004) and Faulkender and Wang (2006) to examine the levels of corporate cash holdings and the marginal value of corporate cash holdings by using a sample of publicly traded U.S. firms. At first, regarding the levels of corporate cash holdings, we find that firms with good corporate governance hold more cash than do those with poor governance. We also find that firms with financial constraints hold more cash than do those without. Firms with good corporate governance and financial constraints hold the most cash reserves, which confirms that the impact of corporate governance on corporate cash holdings is strong when firms are financially constrained. These results appear to be related to financing costs for entrenched managers.

Second, regarding the marginal value of corporate cash holdings, the results show that firms with good (poor) corporate governance have high (low) firm value; however, this relationship only applies to firms that are financially constrained. Our results show that when firms are financially constrained, the relationship between corporate governance and corporate cash holdings is strong. That is, it is hard for firms with financial constraints to raise external financing. They may need to pay more attention to keep the balance of cash holding, especially avoiding not to waste cash due to agency problems (i.e., poor corporate governance). Although the present study has yielded findings that have both theoretical and practical implications, it still has some potential limitations. First, financial constraints and corporate governance examined in this study are not the sole factors affecting corporate cash holdings. Second, how to reconcile various factors in a study needing a more thoughtful analysis. Hence, much more also needs to be known about the determinants of corporate cash holdings. Especially, there is a continuing need for constructing a new research framework to incorporate more factors to investigate and compare the determinants of corporate cash holdings in the future.

\section{REFERENCES}

Acharya, A., H. Almeida, and M. Campello (2007). "Is Cash Negative Debt? A Hedging Perspective on 
Corporate Financial Policies”, Journal of Financial Intermediation, vol. 16(4), p. 515-554

Acharya, V., H. Almeida, and M. Campello (2013). "Aggregate Risk and the Choice between Cash and Lines of Credit”, Journal of Finance, vol. 68(5), p. 2059-2116

Acharya, V., S. Davydenko, and I. A. Strebulaev (2012). "Cash Holdings and Credit Risk", Review of Financial Studies, vol. 25(12), p. 3572-3609

Almeida, H., M. Campello, and M. S. Weisbach (2004). “The Cash Flow Sensitivity of Cash”, Journal of Finance, vol. 59(4), p. 1777-1804

Azar, J. A., J. F. Kagy, and M. C. Schmalz (2016). "Can Changes in the Cost of Carry Explain the Dynamics of Corporate 'Cash' Holdings?” Review of Financial Studies, vol. 29(8), p. 2194-2240

Bates, T. W., M. K. Kathleen, and R. M. Stulz (2009). "Why Do U.S. Firms Hold So Much More Cash Than They Used To?", Journal of Finance, vol. 64(5), p. 1985-2021

Bebchuk, L., A. Cohen, and A, Ferrell (2008). "What Matters in Corporate Governance?", Review of Financial Studies, vol. 22(2), p. 783-827

Begenau, J., and B. Palazzo (2017). "Firm Selection and Corporate Cash Holdings", Working paper, National Bureau of Economic Research.

Campello, M., J. R. Graham, and C. R. Harvey, (2010). "The Real Effects of Financial Constraints: Evidence from a Financial Crisis", Journal of Financial Economics, vol. 97(3), p. 470-487

Denis, D. J., and V. Sibilkov (2009). "Financial Constraints, Investment, and the Value of Cash Holdings", Review of Financial Studies, vol. 23(1), p. 247-269

Dittmar, A., and J. Mahrt-Smith (2007). "Corporate Governance and the Value of Cash Holdings", Journal of Financial Economics, vol. 83(3), p. 599-634

Dittmar, A., J. Mahrt-Smith, and H. Servaes (2003). "International Corporate Governance and Corporate Cash Holdings", Journal of Financial and Quantitative Analysis, vol. 38(1), p. 111-133

Fama, E., and K. French (1993). "Common Risk Factors in the Returns on Stocks and Bonds", Journal of Financial Economics, vol. 33(1), p. 3-56

Faulkender, M., and R. Wang (2006). “Corporate Financial Policy and Value of Firm”, Journal of Finance, vol. 61(4), p. 1957-1990

Foley, H., S. Titman, and G. Twite (2007). "Why do Firms Hold So Much Cash? A Tax-based Explanation", Journal of Financial Economics, vol. 86(3), p. 579-607

Gao, H., J. Harford, and K. Li (2013). "Determinants of Corporate Cash Policy: Insights from Private Firms”, Journal of Financial Economics, vol. 109(3), p. 623-639

Gompers, P. A., J. L. Ishii, and A. Metrick (2003). "Corporate Governance and Equity Prices", Quarterly Journal of Economics, vol. 118(1), p. 107-155

Harford, J., S. Mansi, and W. Maxwell (2008). "Corporate Governance and Firm Cash Holdings in the US”, Journal of Financial Economics, vol. 87(3), p. 535-555

Hsu, P. H., F. Li, and T. C. Lin (2016). "Why Do Innovative Firms Hold More Cash? The International 
Evidence", Working paper

Kalcheva, I., and K. Lins (2007). "International Evidence on Cash Holdings and Expected Managerial Agency Problems”, Review of Financial Studies, vol. 20(4), p. 1087-1112

Keynes, J. M. (1936). “The General Theory of Employment, Interest and Money”, Harcourt Brace, London.

Kim, Chang-Soo, D.C. Mauer, and A.E. Sherman (1998). "The Determinants of Corporate Liquidity: Theory and Evidence", Journal of Financial and Quantitative Analysis, vol. 33(3), p. 305-334

Lee, C., and H. Park (2016). "Financial Constraints, Board Governance Standards, and Corporate Cash Holdings", Review of Financial Economics, vol. 28(January), p. 21-34

Myers, S. C., and R. G. Rajan (1998). “The Paradox of Liquidity”, Quarterly Journal of Economics, vol. 113(3), p. 733-771

Opler, T., L. Pinkowitz, R. Stulz, and R. Williamson (1999). “The Determinants and Implications of Corporate Cash Holdings", Journal of Financial Economics, vol. 52(1), p. 3-46

Pinkowitz, L., and R. Williamson, (2001). "Bank Power and Cash Holdings: Evidence from Japan", Review of Financial Studies, vol. 14(4), p. 1059-1082

Pinkowitz, L., and R. Williamson, (2007). "What is the Market Value of a Dollar of Corporate Cash?", Journal of Applied Corporate Finance, vol. 19(3), p. 74-81

Pinkowitz, L., R. Stulz, and R. Williamson (2006). "Does the Contribution of Cash Holdings and Dividends to Firm Value Depend on Corporate Governance? A Cross-country Analysis", Journal of Finance, vol. 61(6), p. 2725-2751

Ramezani, Cyrus A. (2011). "Financial Constraints, Real Options and Corporate Cash Holdings", Managerial Finance, vol. 37(12), p.1137-1160

Ramirez, A., and S. Tadesse (2007). "Corporate Cash Holdings, National Culture, and Multinationality", William Davidson Institute Working Paper

Yun, H. (2009). "The Choice of Corporate Liquidity and Corporate Governance", Review of Financial Studies, vol. 22(4), p. 1447-1475

\section{ACKNOWLEDGEMENTS}

We are particularly grateful to the editor Terrance Jalbert and the two anonymous reviewers for their insightful comments and suggestions. All the remaining errors are ours.

\section{BIOGRAPHY}

Wenchien Liu is an Assistant Professor in Department of Finance, Chung Yuan Christian University. He can be reached at 200 Chung Pei Road, Chung Li District, Taoyuan City, Taiwan. Phone: 886-3-2655706. Email:wcliu@cycu.edu.tw. 